\title{
CHANGES IN GREEK INDUSTRY AND THEIR EFFECT ON AIR POLLUTANT EMISSIONS
}

\section{G. TSILINGIRIDIS*}

Accepted: $24 / 10 / 08$

\author{
Aristotle University of Thessaloniki \\ Department of Mechanical Engineering \\ Process Equipment Design Laboratory, P.O. Box 487 \\ GR 54124 Thessaloniki, Greece
}

\begin{abstract}
Energy use in Greek Industry, fuel mix changes and contribution of major sectors from 1960 to 2004 are presented and analysed. Energy related air pollutant emissions are estimated and presented too.

Energy use in Industry has shown a growing trend. Residual fuel oil was the predominant energy form, but with decreasing share, while electricity had a remarkable and steadily increasing share, reflecting changes in industrial equipment towards more automated production processes. Natural Gas started to contribute to energy mix in late '90s. Emissions followed energy's growth but with lower rates, since 'dirty fuels' use grew slower than electricity, which is a 'clean fuel' in final uses. Sectors with the greater contribution in energy use and air pollutant emissions were 'Basic Metals' and 'Chemical' from 1960 to 1975, while after 1985 'Non-metallic Minerals' and 'Energy' sectors had the greater contribution.

More than $50 \%$ of the countries industrial units are located close to Athens. In 2003, Attica's share to total industry's emissions was lower than the share of industries, while neighbouring prefectures' share was higher. The share of 'dirty' industries is higher in the neighbouring to Attica prefectures, while in Attica the share of industries using mainly electricity ('clean' final energy form) is higher.

The enlargement of natural gas penetration together with energy saving measures will affect positive any emission reduction policy.
\end{abstract}

KEYWORDS: Fuel mix, energy, final energy consumption, industry, sectoral change, Greece.

\section{INTRODUCTION}

Energy is used in every human activity, and it is a worldwide index of a country's development level. Changes of a country's social and financial status have an impact on the use of energy as well. There is a direct relation between energy use and air pollution with hazardous impact on the environment and so far, economic prosperity of a nation is, inevitably, strongly connected with a heavily polluted environment. Industry, Transportation and the Residential sector are on global as well as in national level, the three major final energy use sectors.

Since 1960, important economic, political and social changes have taken place in Greece, and, as a result, great variations concerning the energy used by all sectors of economic activities can be seen. Although in the '60s and early '70s Industry covered the larger part of final energy use in Greece, after the '80s it became the second larger contributor, covering $21 \%$ of final energy use in 2004. Transportation became the largest one and covered $38 \%$ of final energy in 2004 (Greek Min. of Development, 2008). Similar variations were detected, concerning the air pollutants produced from the activities in these sectors. Energy related activities (production, transformation and use) are the major air polluters for almost all air 
pollutants. Following that, Industry emits a large portion of greenhouse gases and is the major emitter of $\mathrm{SO}_{2}$. According to European Environmental Agency in 1996 industrial sources contributed about $20 \%, 17 \%$ and $22 \%$ for $\mathrm{SO}_{2}, \mathrm{NO}_{x}$ and $\mathrm{CO}_{2}$ respectively, to total $\mathrm{EU}$ emissions of air pollutants (European Environment Agency, 2000), while in 2004 the manufacturing industry contributed $17 \%$ in particulate matter, $15 \%$ in ground-level ozone formation precursors and $14 \%$ in acidifying substances (European Environment Agency, 2007a).

In Greece and in national level, according to 1990 data (Christolis et al., 1995), the share of Industry in $\mathrm{NO}_{\mathrm{x}}, \mathrm{VOC}, \mathrm{CO}$ and $\mathrm{CO}_{2}$ emissions was $16 \%, 1 \%, 1 \%$ and $14 \%$ respectively, while the $\mathrm{SO}_{2}$ emissions were $18 \%$ (Tsilingiridis, 1995). In the local level the share of Industry in total anthropogenic emissions can be larger. In Greater Area of Athens (Attica and parts of neighbouring prefectures) in 1993 industrial $\mathrm{SO}_{2}, \mathrm{NO}_{\mathrm{x}}, \mathrm{VOC}$ and $\mathrm{CO}$ emissions (including power generation) contributed $94 \%, 26 \%, 1 \%$ and $1 \%$ (Tsilingiridis et al., 1997) respectively, while in Thessaloniki in 1995 the contribution was 86\%, 22\%, 8\% and 1\% (Tsilingiridis et al., 2002).

In the present paper changes in energy mix composition and in the contribution of the main industrial sectors in Greek Industry from 1960 to 2004 are analysed. The impact of energy mix composition changes to air pollutant emissions is investigated and the allocation of emissions to main industrial sectors is presented. Additionally, the distribution of emissions in the country's geographic regions is examined.

\section{METHODS}

In this work only energy-related emissions, which are released by a controlled combustion process and are mainly characterised by the types of fuels used, are considered. The estimation of emissions followed the CORINAIR methodology, as it is presented in EMEP/CORINAIR Atmospheric Emission Inventory Guidebook (European Environment Agency, 2007b). Emission calculations were carried out for air pollutants $\mathrm{SO}_{2}, \mathrm{NO}_{x}, \mathrm{VOC}$, $\mathrm{PM}_{10}$ and $\mathrm{CO}_{2}$, according to the following equation:

\section{Emission = Activity Level $\times$ Emission Factor}

The combustion installations in Greece, boilers and furnaces, are small-sized with thermal capacity of less than $50 \mathrm{MW}$. Other combustion sources such as internal combustion engines and gas turbines are seldom used. During the '90s a few large plants (refineries, sugar factories, natural gas fields) installed gas turbines for their own power use. This activity is classified in the 'Combustion in energy and transformation industries' sector, which is not included in the present analysis.

Activity Level and emission factors are defined on the same additive level (fuel used). Emission factors are related with the fuel's individual characteristics and with technologically defined parameters. $\mathrm{SO}_{2}$ and $\mathrm{CO}_{2}$ emission factors have been calculated on the basis of mass balance and are depended on $S$ and $C$ content of fuels. Throughout the study, EMEP/CORINAIR emission factors sources is used, since emission factors are considered to be fully representative of the Greek situation (Tsilingiridis, 1995). The TNO emission factors dataset (TNO-MEP, 2005) is used for the calculation of $\mathrm{PM}_{10}$ emissions.

Emission estimations carried out using aggregated values for each industrial sector and for each country's region. All necessary activity level data (fuels consumption) were available from Ministry of Development (Greek Min. of Development, 2008), International Energy Agency (International Energy Agency) and National Statistical Service of Greece (NSSG) (National Statistical Service of Greece).

Energy forms used in Greek Industry in the examined period have been classified in eight major categories according to their characteristics and uses, as well as their importance in energy mix:

- Electricity

- Coal

- Other solid fuels: lignite, oven/gas coke, briquettes (BKB), petroleum coke

- Refinery gas 
- Natural gas

- $\quad$ Other gases: LPG, gas works gas, coke ovens/blast furnaces gas

- $\quad$ Diesel (light fuel oil)

- Residual fuel (heavy fuel oil)

- $\quad$ Other fuels (biomass, kerosene, gasoline).

Natural gas has been used in small quantities in oil/gas field plants and in Chemical Industry since 1982. Actually, natural gas started to be used in Greece, first in Industry, since 1997, imported from Russia. Coke ovens/blast furnaces gas have been used in small quantities only from 1967 to 1981. Biomass, kerosene and gasoline are used in small quantities, too.

According to NSSG all industrial activities are classified in 23 different categories (International Labour Organization Industrial classification, 2008). On the other hand, in Energy Statistics all industrial activities are classified in 13 different categories (Greek Min. of Development, 2008). In the present work the Energy Statistics classification is followed, and the six most important categories, which use more than $80 \%$ of industry's energy, are examined separately. They are:

- Energy Sector (own use and distribution loses in: lignite mines, oil and gas extraction, petroleum refineries, power plants, pumped storage, BKB plants, gas works, coke plants)

- Basic Metals (iron and steel, non-ferrous metals)

- Chemical

- Non-Metallic Minerals (cement, gypsum, etc)

- Food \& Tobacco

- Textiles \& Leather

- Other sectors (Mining and Quarrying, Constructions and other non-classified industries).

This aggregated classification is more suitable for technical analysis, presentation and comparisons than the statistical service classification, since the important categories from the energy point of view are just a few. It has to be noticed that 'Energy Sector' does not include the quantities of fuels transformed to other energy forms (mainly lignite and other fuels to electricity or crude oil to oil products), but only the energy used for operation of equipment (own use) of Energy Sector. In emissions inventorying the energy forms transformation are classified in the 'Combustion in energy and transformation industries' sector, and are examined separately (European Environment Agency, 2007b).

\section{RESULTS}

In Table 1 the evolution of final energy consumption (FEC) in Greek Industry from 1960 to 2004 is presented together with the related emissions. In Figure 1 the evolution of energy and air pollutant emissions indexes are presented. $\mathrm{PM}_{10}$ emissions are average values of maximum and minimum values calculated for all fuel and sectors.

During the period 1960-2004 total FEC in Industry has shown a growing trend, which in the case of electricity was remarkable. Total FEC in 2004 had Increase Index of 911 compared to 1960 (ref. year $1960=100$ ), while electricity had Increase Index of 1845. Emissions followed this growth but with lower rates, since 'dirty fuels' in energy mix grew slower than electricity, which is a 'clean fuel' in final use. Industrial energy and emission indexes have shown an upward trend till to 1980, which was greater in the '60s. After $1980 \mathrm{FEC}, \mathrm{CO}_{2}$ and $\mathrm{NO}_{\mathrm{x}}$ indices have shown slowdown, $\mathrm{PM}_{10}$ index has shown stagnation and $\mathrm{SO}_{2}$ index great reduction, which can be explained by the use of low $S$ liquid fuels in Attica after 1981. Only VOC emission index has shown a continuous growth up to 2000, which can be explained by the changes in energy mix and more specifically by the increased use of coal and other solid fuels after 1980 (Figure 2). After 2000 there was a slight slowdown in FEC and emission indexes. This must be attributed to the large decrease of the operated industrial plants after 2001 (Table 2) and also to the natural gas use, which started in 1997 (Figure 2).

The influence of important factors, such as energy intensity and industrial output level, together with the influence of fuel mix and structural changes, on energy and $\mathrm{CO}_{2}$ emission 
changes in Greek Industry has been analysed for the period 1985-1995 in previous work (Mavrotas et al., 2000).

Table 1. Evolution of final energy consumption and energy related air pollutant emissions in Greek Industry

\begin{tabular}{lrrrrrrrrrrr}
\hline & & 1960 & 1965 & 1970 & 1975 & 1980 & 1985 & 1990 & 1995 & 2000 & 2004 \\
\hline $\begin{array}{l}\text { FEC } \\
\text { of which } \\
\text { electricity [GWh] }\end{array}$ & [Mtoe] & 0.683 & 1.298 & 2.512 & 3.923 & 4.892 & 4.481 & 5.311 & 5.516 & 6.500 & 6.227 \\
\hline $\mathrm{SO}_{2}$ & {$[\mathrm{kt}]$} & 34.95 & 61.98 & 105.04 & 168.67 & 218.98 & 109.39 & 119.29 & 109.01 & 119.79 & 123.81 \\
$\mathrm{NO}_{\mathrm{x}}$ & {$[\mathrm{kt}]$} & 4.03 & 8.15 & 13.05 & 20.19 & 24.96 & 19.80 & 23.64 & 23.79 & 27.17 & 26.34 \\
$\mathrm{NMVOC}$ & {$[\mathrm{kt}]$} & 0.37 & 0.61 & 1.24 & 1.24 & 2.20 & 3.23 & 3.46 & 3.62 & 4.77 & 3.39 \\
$\mathrm{CH}_{4}$ & {$[\mathrm{kt}]$} & 0.08 & 0.13 & 0.23 & 0.36 & 0.47 & 0.38 & 0.45 & 0.56 & 0.71 & 0.57 \\
$\mathrm{CO}$ & {$[\mathrm{kt}]$} & 0.46 & 1.29 & 1.86 & 2.85 & 2.90 & 1.82 & 2.12 & 3.47 & 5.32 & 4.76 \\
$\mathrm{PM}_{10}$ & {$[\mathrm{kt}]$} & 2.42 & 4.58 & 7.16 & 10.85 & 13.06 & 11.72 & 13.07 & 13.31 & 14.10 & 12.68 \\
$\mathrm{CO}_{2}$ & {$[\mathrm{Gt}]$} & 1.87 & 3.56 & 6.01 & 9.40 & 11.57 & 10.66 & 12.32 & 12.61 & 14.42 & 12.84 \\
\hline
\end{tabular}

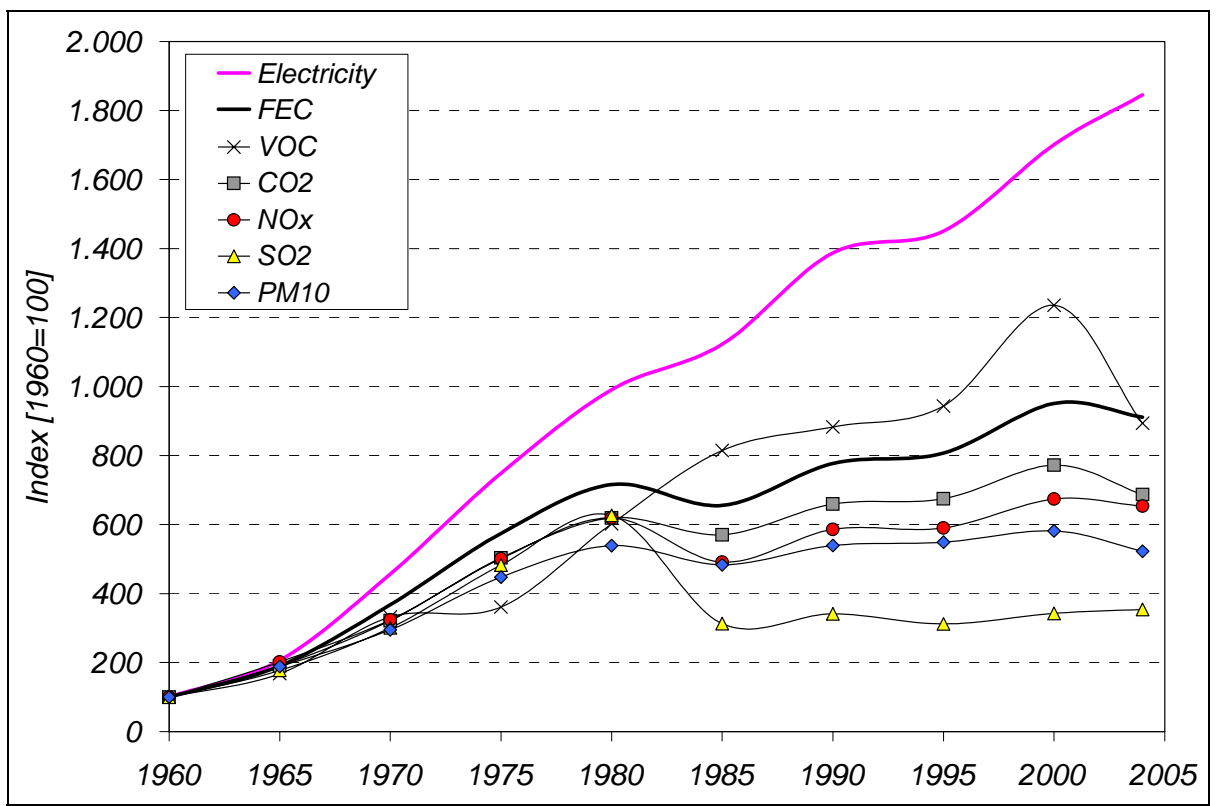

Figure 1. Evolution of total final energy consumption electricity and emissions indexes in Greek Industry

\subsection{Fuel mix}

In Figures 2 and 3 the contribution of main fuels and industrial sectors to total energy use in Greek industry during the period 1960 to 2004 are presented. From 1960 to 1980 the most significant energy form used in Industry was residual oil, which steadily decreased its share from more than $60 \%$ in 1960 to $19 \%$ in 2004 . Electricity had a steadily increasing share, from $18 \%$ in 1960 to $35 \%$ in 2004, reflecting changes in industrial equipment towards more automated production processes. Solid fuels, mainly coke had a significant contribution in 'Iron and Steel' industry (Basic Metals) in the '60s and the '70s, while coal and petroleum coke had a significant contribution in 'Cement' industry (Non-Metallic Minerals) in the '80s and the '90s. Refinery gas had a steadily increasing share, due to the increase of crude oil treated in the four refineries ('Energy' sector). Remarkable characteristic of industry's energy mix up to 1997 is, practically, the absence of natural gas, a major lack in all Greek energy mix. In 2004 natural gas covered about 7\% of total energy used in industry.

In 1960 'Other sectors' (45\%) and 'Chemical' (29\%) covered the largest part of energy used, while in 2004 the 'Energy' (35\%) and 'Non-Metallic Minerals' (19\%) sectors. Reduction in energy use in 1985 is attributed to activity reduction in 'Basic Metals', and mainly 'Iron and Steel' industries. 
Figure 3 reveals the enlargement of dynamic and exporting sectors such as 'Energy', 'NonMetallic Minerals', 'Basic Metals' and 'Food \& Tobacco'.

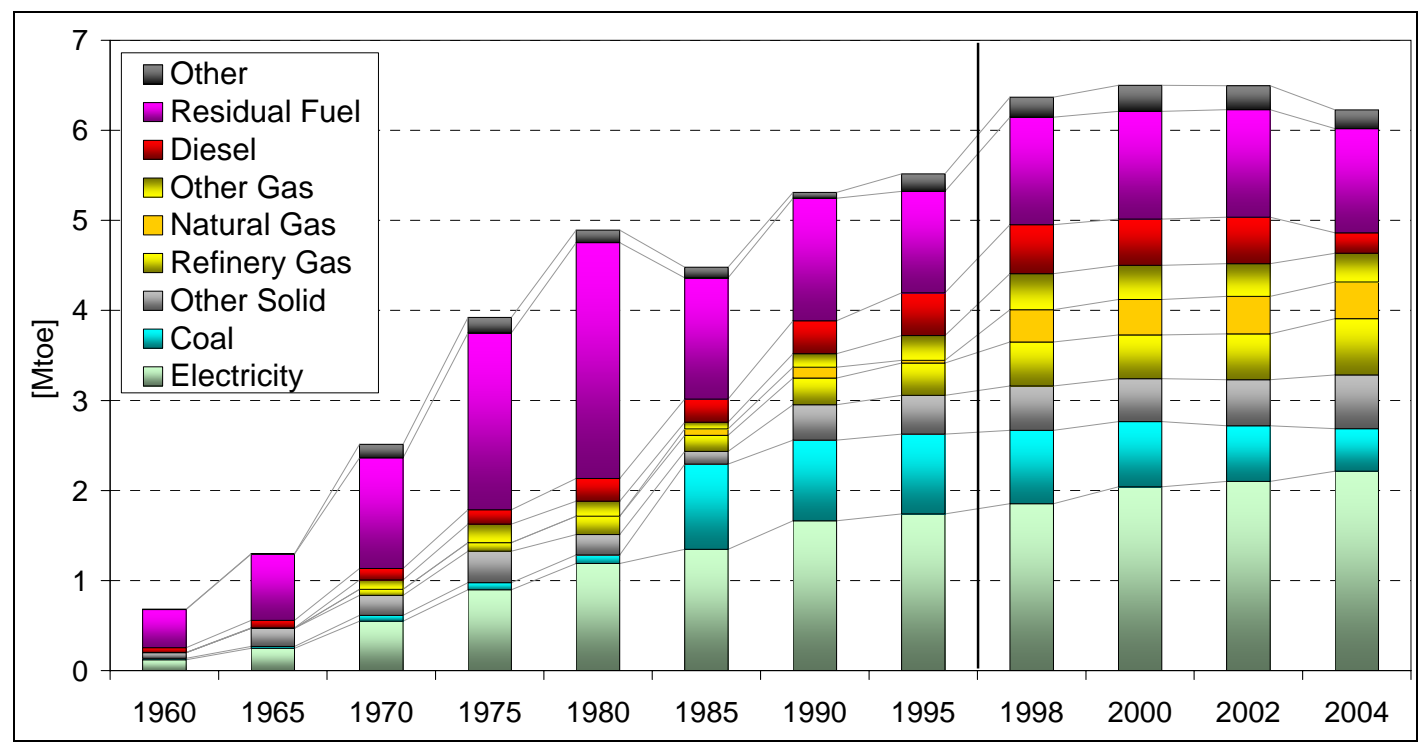

Figure 2. Evolution of energy use in Greek Industry by fuel

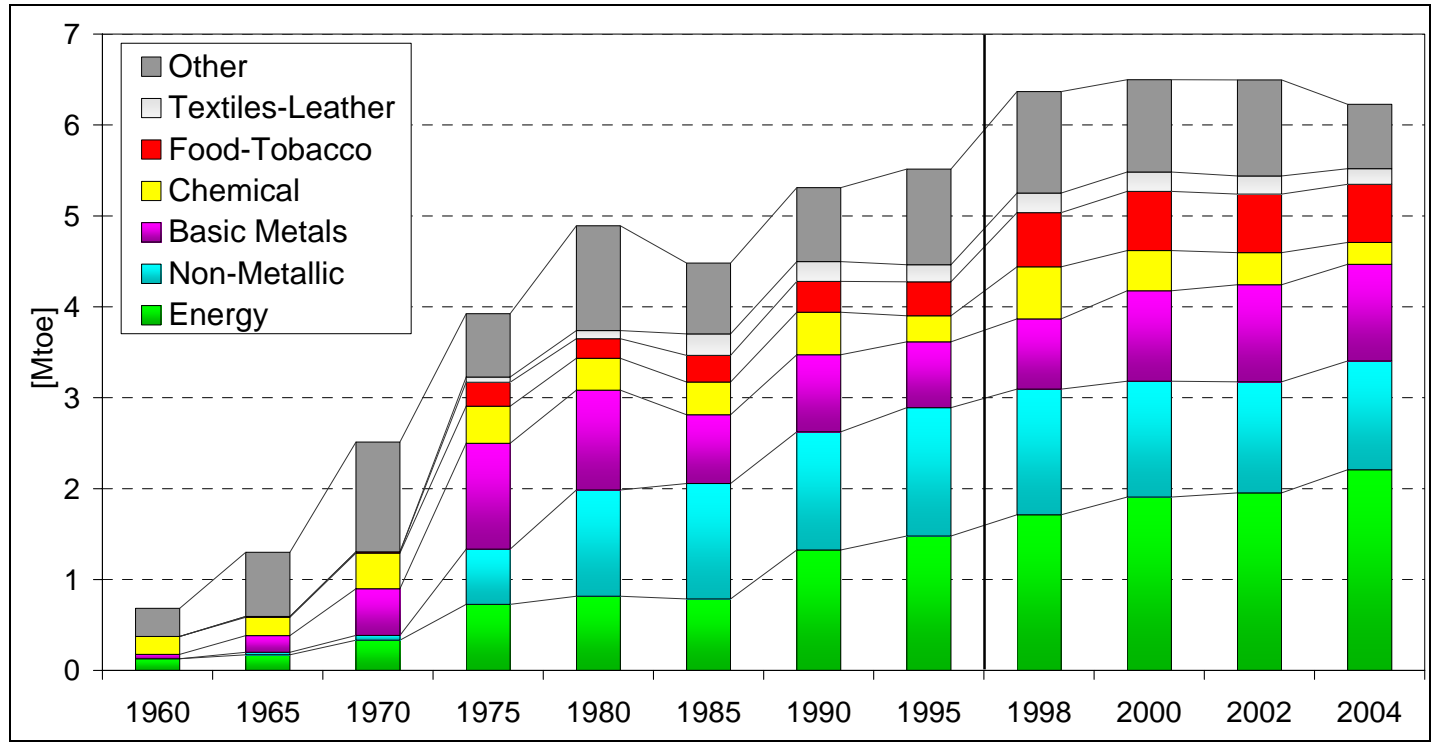

Figure 3. Evolution of energy use in Greek Industry by sector

\subsection{Emissions}

In Figures 4 to 7 the emissions from each fuel used and from each main sector of Greek Industry from 1960 to 2004 are presented. All emissions show an great increase from 1960 to 1980 and a drop in 1985. From 1985 to 1998 there is a moderate increase, which after 1998 ad up to 2004 terns to a decrease for $\mathrm{NO}_{\mathrm{x}}, \mathrm{CO}_{2}$ and $\mathrm{PM}_{10}$. Emissions evolution reflects the energy mix changes, the cross-sectional activity changes, and in the case of $\mathrm{SO}_{2}$ the reduction of $\mathrm{S}$ content in oil liquid fuels used in Attica, since 1981.

- $\mathrm{SO}_{2}$ emissions (Figure 4): Residual fuel is the predominant fuel but with a high reduction after 1980 (89\% in 1960, 50.5\% in 2004). Refinery gas has shown a significant increase after '90s (33\% in 2004). 'Energy' sector (mainly refineries) and 'Non-metallic minerals' (mainly cement industry) are the major emission contributors.

- $N O_{x}$ emissions (Figure 5): Residual fuel is the predominant fuel $(80 \%$ in $1960,33 \%$ in 2004) with a significant share of solid fuels (16\% in $1960,34 \%$ in 2004). 'Non-Metallic 
Minerals' (mainly cement industry) and 'Energy' sector (mainly refineries) are the major emission contributors.

- $\mathrm{CO}_{2}$ emissions (Figure 6): Residual fuel is the predominant fuel $(74 \%$ in $1960,23 \%$ in 2004) with a significant share of solid fuels (17.5\% in 1960, 31.5\% in 2004). 'Non-Metallic Minerals' (mainly cement industry) and 'Energy' sector (mainly refineries) are the major emission contributors.

- $P M_{10}$ emissions (Figure 7): Residual fuel is the predominant fuel in $1960(75 \%)$ decreasing its share to $39 \%$ in 2004. Solid fuels in 1960 covered 25\%, while in 2004 they covered $44 \%$. 'Non-metallic minerals' is the major emission contributors.

Analysis of air pollutants concentration measurements in Athens for the period 1987-1997 showed a decrease in $\mathrm{SO}_{2}, \mathrm{NO}_{x}$ and in Black Smoke concentrations (Kalabokas et al., 1999). In Thessaloniki, air pollutants concentration measurements for the period 1988-1999 showed also a decrease in $\mathrm{SO}_{2}, \mathrm{NO}_{\mathrm{x}}, \mathrm{PM} 10$ and TPS (Kelessis, 2001; Nikolaou and Papadakis, 2001). The primary cause of the decreasing trends in air pollutant concentrations seems to be the pollution abatement measures taken by the state authorities, mainly consisting in the replacement of the old technology gasoline-powered private cars and the reduction of the sulphur content in diesel oil. On the contrary, industrial emissions in the same period (1985 1998) showed $41 \%$ increase of $\mathrm{NO}_{\mathrm{x}}, 23 \%$ of $\mathrm{PM}_{10}$ and $10 \%$ of $\mathrm{SO}_{2}$ emissions.

As it has been concluded in other works, too (Mavrotas et al., 2000), further enlargement of natural gas penetration together with energy saving measures will affect positive any emission reduction policy in industry.

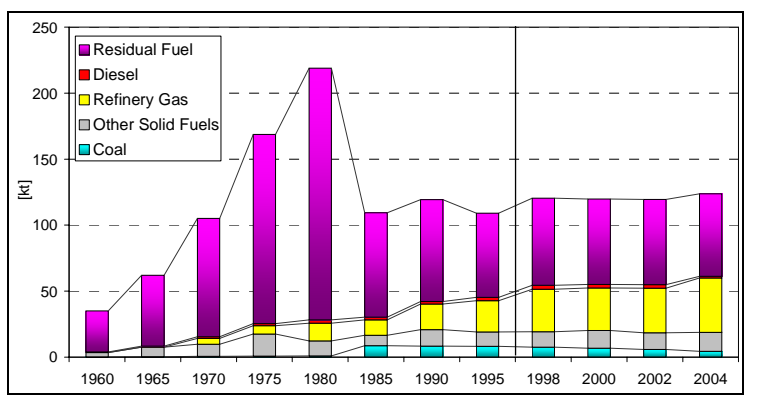

(a)

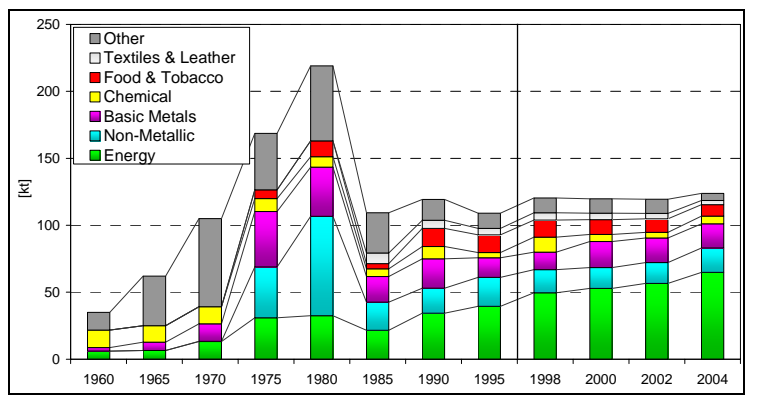

(b)

Figure 4. Evolution of energy related $\mathrm{SO}_{2}$ emissions in Greek Industry (a) by fuel and (b) by sector

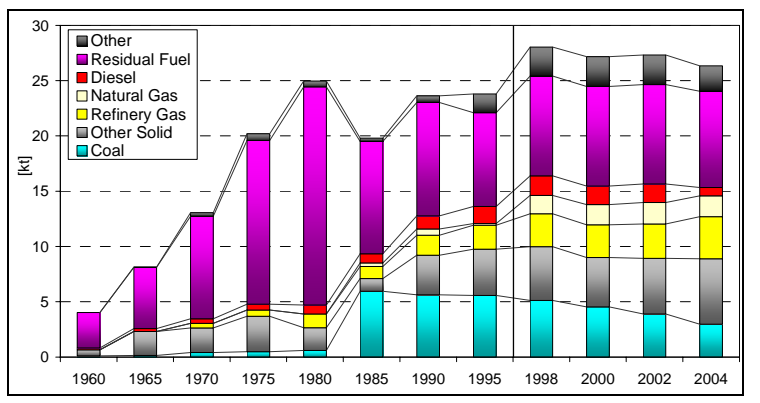

(a)

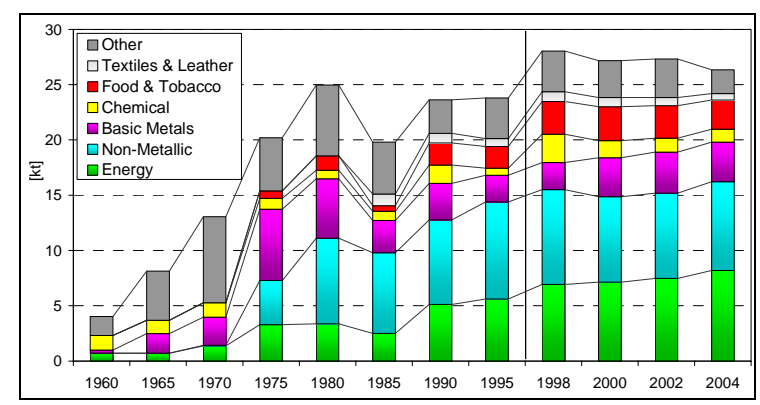

(b)

Figure 5. Evolution of energy related $\mathrm{NO}_{\mathrm{x}}$ emissions in Greek Industry

(a) by fuel and (b) by sector 


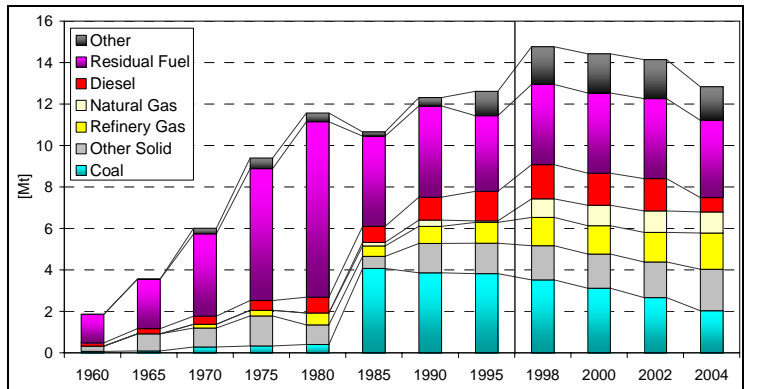

(a)

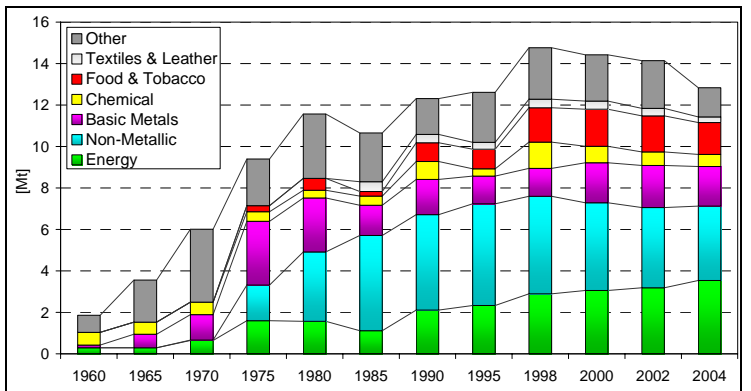

(b)

Figure 6. Evolution of energy related $\mathrm{CO}_{2}$ emissions in Greek Industry (a) by fuel and (b) by sector

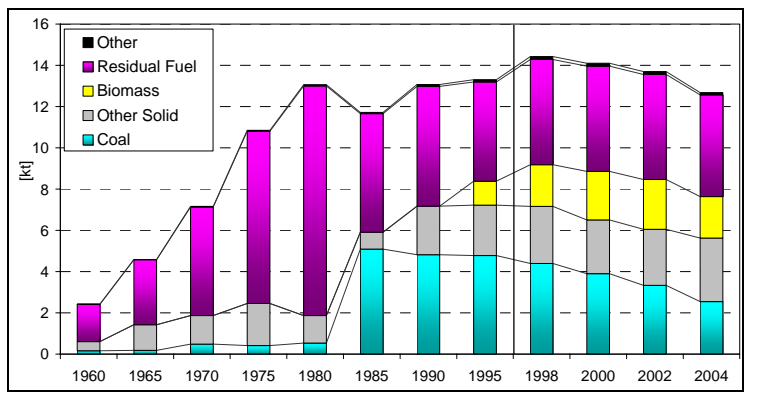

(a)

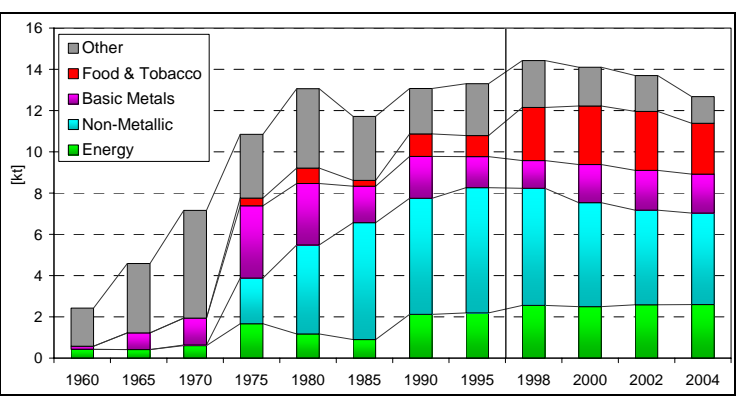

(b)

Figure 7. Evolution of energy related $\mathrm{PM}_{10}$ emissions in Greek Industry

(a) by fuel and (b) by sector

\subsection{Geographical distribution}

The evolution of total number of industrial plants, as well as their geographical distribution, from 1993 to 2003 are presented in Table 2 and in Figure 8. The geographical regions with the higher concentration of industrial units and the larger contribution in air pollutant emissions are presented in Figure 9 in more detail. The majority of industries are located around two major areas. Around Athens, country's capital, in Attica-9, Boeotea-10, Eboea-7a and Corinth-8a, is located more than $50 \%$ of the countries industrial plants and close to Thessaloniki, northern Greece, about $17 \%$, i.e. more than $2 / 3$ of the Industry in Greece. It has to be noted that the majority of the large size plants (refineries, cement industries, metal industries, etc) is located in the abovementioned areas, too.

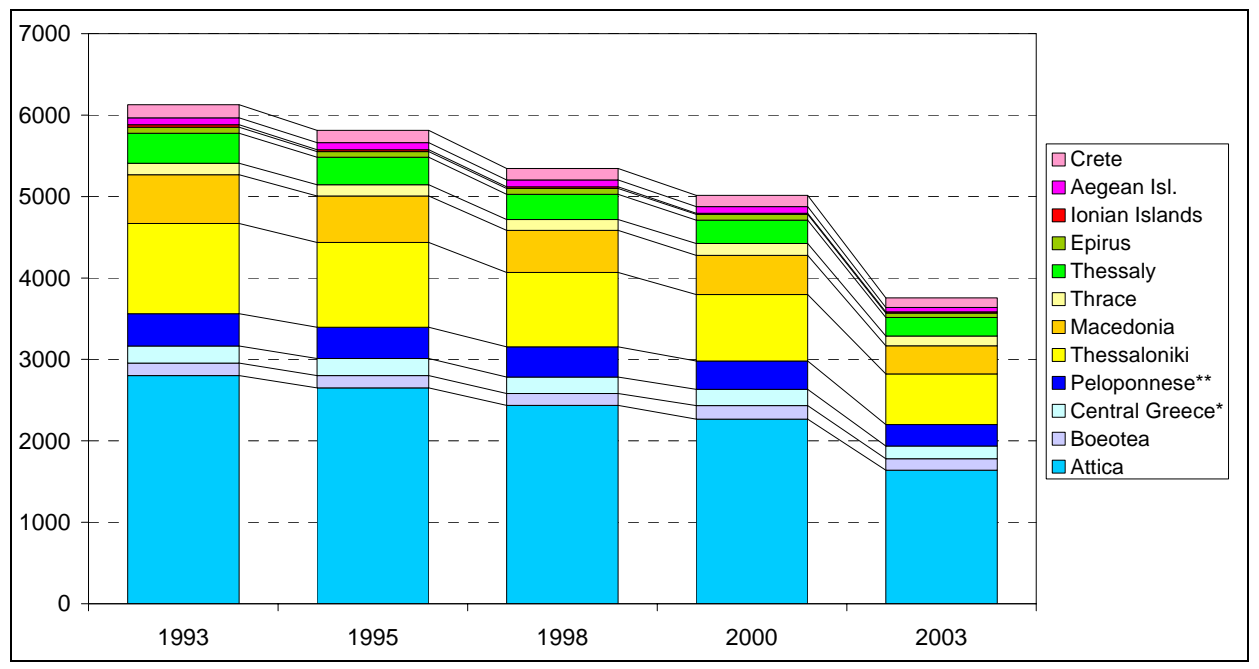

Figure 8. Distribution of industrial plants in major geographical regions (* including 7a: Eboea, **including 8a: Corinth, Figure 9) 
Table 2. Distribution of industrial plants and energy related emissions in major geographical regions

\begin{tabular}{|l|rrrrr|rrrr|}
\hline \multirow{2}{*}{ Region } & \multicolumn{5}{|c|}{ Nr. of Units } & \multicolumn{4}{c|}{ Pollutant (year: 2003) } \\
\cline { 2 - 10 } & $\mathbf{1 9 9 3}$ & $\mathbf{1 9 9 5}$ & $\mathbf{1 9 9 8}$ & $\mathbf{2 0 0 0}$ & $\mathbf{2 0 0 3}$ & \multicolumn{1}{|c|}{$\mathrm{SO}_{2}$} & NO $_{\mathbf{x}}$ & $\mathbf{P M}_{\mathbf{1 0}}$ & $\mathbf{C O}_{\mathbf{2}}$ \\
\hline 1. Thrace & $2.3 \%$ & $2.4 \%$ & $2.5 \%$ & $2.9 \%$ & $3.2 \%$ & $2.6 \%$ & $2.7 \%$ & $3.3 \%$ & $2.6 \%$ \\
2. Macedonia & $9.8 \%$ & $9.8 \%$ & $9.7 \%$ & $9.6 \%$ & $9.2 \%$ & $4.4 \%$ & $6.7 \%$ & $7.4 \%$ & $6.6 \%$ \\
3. Thessaloniki & $18.1 \%$ & $17.9 \%$ & $17.1 \%$ & $16.3 \%$ & $16.6 \%$ & $13.3 \%$ & $12.5 \%$ & $10.5 \%$ & $12.5 \%$ \\
4. Epirus & $1.2 \%$ & $1.2 \%$ & $1.3 \%$ & $1.4 \%$ & $1.4 \%$ & $0.4 \%$ & $0.9 \%$ & $1.1 \%$ & $0.9 \%$ \\
5. Ionian Islands & $0.5 \%$ & $0.4 \%$ & $0.4 \%$ & $0.3 \%$ & $0.4 \%$ & $0.1 \%$ & $0.3 \%$ & $0.4 \%$ & $0.3 \%$ \\
6. Thessaly & $6.0 \%$ & $5.8 \%$ & $5.8 \%$ & $5.7 \%$ & $6.1 \%$ & $6.9 \%$ & $10.4 \%$ & $14.8 \%$ & $12.0 \%$ \\
7. Central Greece* & $3.4 \%$ & $3.6 \%$ & $3.8 \%$ & $4.0 \%$ & $4.2 \%$ & $4.6 \%$ & $6.5 \%$ & $9.4 \%$ & $7.2 \%$ \\
8. Peloponnesus * & $6.5 \%$ & $6.6 \%$ & $6.9 \%$ & $6.9 \%$ & $7.0 \%$ & $22.5 \%$ & $8.5 \%$ & $7.8 \%$ & $7.7 \%$ \\
9. Attica & $45.8 \%$ & $45.6 \%$ & $45.6 \%$ & $45.2 \%$ & $43.7 \%$ & $34.5 \%$ & $40.3 \%$ & $32.9 \%$ & $39.7 \%$ \\
10. Boeotea & $2.5 \%$ & $2.6 \%$ & $2.7 \%$ & $3.3 \%$ & $3.7 \%$ & $9.9 \%$ & $8.4 \%$ & $9.0 \%$ & $7.7 \%$ \\
11. Aegean Islands & $1.4 \%$ & $1.5 \%$ & $1.6 \%$ & $1.6 \%$ & $1.4 \%$ & $0.3 \%$ & $0.9 \%$ & $1.2 \%$ & $0.9 \%$ \\
12. Crete & $2.6 \%$ & $2.6 \%$ & $2.6 \%$ & $2.8 \%$ & $3.2 \%$ & $0.6 \%$ & $1.8 \%$ & $2.3 \%$ & $1.8 \%$ \\
\hline Total [kt y ${ }^{-1}$ ] & 6120 & 5814 & 5344 & 5016 & 3753 & 109.9 & 25.4 & 12.2 & 12920 \\
\hline
\end{tabular}

(* including 7a: Eboea, ${ }^{\star *}$ including 8a: Corinth, figure 9)

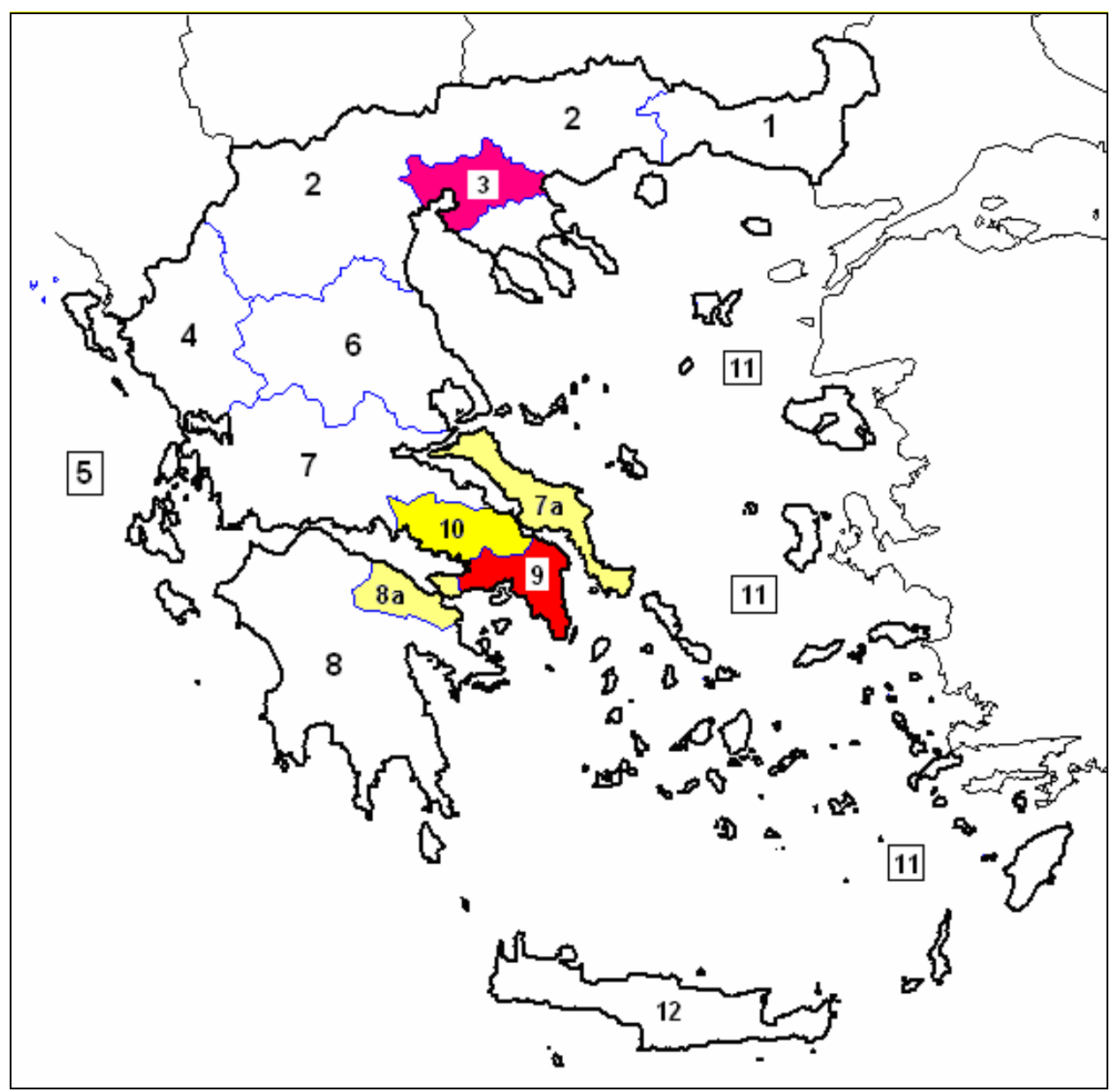

Figure 9. Geographical regions with the larger concentration of industrial units and emissions 
Total number of industries decreased from 6120 in 1993 to 3753 in 2003, i.e. by $37 \%$. Thessaloniki had the largest reduction and its share decreased from $18,1 \%$ to $16,6 \%$. The share of Attica decreased from $46 \%$ to $44 \%$, while the share of neighbouring regions, Boeotea, Central Greece and Peloponnese, had an increase of $1.2 \%, 0.8 \%$ and $0.5 \%$ respectively.

In table 2 the geographical distribution of 2003 emissions is presented, too. As a result of the high share of industrial plants, as well as the size of industries, the largest part of air pollutants is emitted around Athens. In 2003 33\% to $40 \%$ of the total industrial emissions, depending on the pollutant, has been emitted in Attica. The lower contribution to total emissions, compared to the concentration of industries (44\%), is mainly due to: (a) lower sulfur content of liquid fuels in Attica since early '80s, (b) higher share of industries located in Attica, which mainly use electricity ('clean' final energy form), such as machinery or transport equipment industries.

The situation in Attica has to be associated with the situation in neighbouring prefectures. Boeotea-10, has a contribution in emissions ranging from $8 \%$ to $10 \%$, with only $4 \%$ of the industries. The same holds true for Eboea-7a, and Corinth-8a, meaning that a large number of 'dirty' industries have "moved" from Attica to the neighbouring prefectures. This fact makes clear that Attica's atmospheric environment is influenced by all surrounding emissions sources, since air movements transport air pollutants to long distances (Michopoulos et al., 2006; Koulouri et al., 2008), and any study of air pollution in Attica has to take into account the activities taking place in all neighbouring areas.

In Thessaloniki-3 in 2003 were emitted $10.5-13.3 \%$ of total industrial emissions, depending on the pollutant, having only $16.6 \%$ of total industries. This can be attributed to the higher rates of natural gas penetration in Industry than in other regions. For the same reason Macedonia (2) with $9.2 \%$ of the industries contributes only $4.4 \%$ to $7.4 \%$ in emissions.

\section{CONCLUSIONS}

Energy use in Industry has shown an increased trend during the period 1960-2004. Emissions, except $\mathrm{SO}_{2}$ which had great reduction after 1981, followed this trend but with lower rates, since 'dirty fuels' in energy mix grew slower than electricity, which is a 'clean fuel' in final use. Electricity has shown the highest growth rates and by the end of the period examined covers $36 \%$ of energy used in industry. Residual fuel was the predominant fuel until 1980 , covering up to $54 \%$ of total final energy consumption in industry. After 1980 it had a steadily reduced share in Industry's fuel mix, covering in 2004 only $18.5 \%$ of energy used. Remarkable characteristic of industry's energy mix is the absence of natural gas up to 1997, which is a major lack in total Greek energy mix. In 2004 natural gas covered only $7 \%$ of total energy used in industry.

From 1960 to 1975 'Basic Metals' and 'Chemical' sectors had the greater contribution in energy use and air pollutant emissions, while 'Non-metallic Minerals' and 'Energy' sectors had the greater contribution after 1985.

The majority of industries, especially the large size plants, are mainly located around country's capital, Athens, (Attica, Boeotea, Eboea, Corinth) and secondarily close to Thessaloniki. As result, the largest part of industrial air pollutants is emitted in these areas.

\section{REFERENCES}

- Christolis M., Keramida E., Brillaki D., Fragioudakis K., Samaras Z., Tsilingiridis G. and Sakellariadou F., (1995), Climate Change: The Greek programme for the limitation of $\mathrm{CO}_{2}$ and other emissions of greenhouse gases. Technical Report. Vol. 1: Inventory of emissions of greenhouse gases for the year 1990, Final Report to the Min. of the Env., Urban Planning and Public Works, Athens, 1995.

- Greek Min. Of Development, Energy Balance of Greece: Year 2004, Internet site: http://195.251.42.2/cgi-bin/nisehist.sh (accessed: Jan. 2008).

- European Environment Agency (2000), Emissions of atmospheric pollutants in Europe, 19801996. Internet site:http://reports.eea.eu.int/Topic_report_No92000/en (accessed: Feb. 2008).

- European Environment Agency (2007a), Air Pollution in Europe 1990-2004. EEA Report No2 ISSN 1725-9177, Copenhagen 2007.2 Internet site: 
http://reports.eea.europa.eu/eea report 2007 2/en/Air pollution in Europe 1990 2004.pdf (accessed: Feb. 2008).

- European Environment Agency (2007b), EMEP/CORINAIR Emission Inventory Guidebook 2007 update. Internet site: http://reports.eea.eu.int/technical_report_2001_3/en (accessed: Feb. 2008).

- International Energy Agency, Energy statistics of OECD countries: Years 1960-1998.

- International Labour Organization Industrial classification, International Standard I: Industrial Classification Of All Economic Activities (ISIC), Third Revision, Internet site: http://www.ilo.org/public/english/bureau/stat/class/isic.htm (accessed: Feb. 2008).

- National Statistical Service of Greece, Directorate of Industry, Fuel tables for the years 1993 to 2003 (derived electronically).

- Kalabokas P.D., Viras L.G., Reparis C.C., (1999), Analysis of the 11-year record (1987-1997) of air pollution measurements in Athens, Greece, Global NEST: the Int. J., 1(3), 157-167.

- Kelessis A.G., (2001), Eleven years of primary air-pollutant observation in the city of Thessaloniki, Fresenius Enviromental Bulletin, 10(7), 624 - 628.

- Koulouri E., Grivas G., Gerasopoulos E., Chaloulakou A., Mihalopoulos N., Spyrelis N., (2008), Study of size-segregated particle $\left(\mathrm{PM}_{1}, \mathrm{PM}_{2.5}, \mathrm{PM}_{10}\right)$ concentrations over Greece, Global NEST Journal, 10(2), 132-139.

- Mavrotas G., Pavlidou S., Hondou V., Diakoulaki D., (2000), Decomposition analysis of $\mathrm{CO}_{2}$ emissions from the Greek manufacturing sector, Global NEST: the Int. J., 2,(1), 119-127.

- Michopoulos J., Maggos Th., Vasilakos Ch., Bartzis J.G., Gika E., Hiskia A., (2006), Concentrations measurements and chemical characterization of $\mathrm{PM}_{2.5}$ at an industrial costal site, Global NEST Journal, 8(3), 252-259.

- Nikolaou K. and Papadakis N., (2001), Ten years trends of the urban air pollution in Thessaloniki. Part I: The primary pollutants, Fresenius Enviromental Bulletin, 10(1), 69 - 72.

- TNO-MEP, (2005), CEPMEIP Emission factors for particulate matter. http://www.air.sk/tno/cepmeip/ (accessed: Feb. 2008).

- Tsilingiridis G., (1995), Temporal and spatial analysis of energy use and the resulting air pollutant emissions in Greece (1960-'90), PhD Thesis, Dept. of Mech. Eng, Aristotle University, Thessaloniki.

- Tsilingiridis G., Mimilidis M., Aslanoglou M., Papageorgiou J. and Samaras Z., (1997), Estimation of air pollutants emission density in Attiki using GIS technology, In: Proc. $5^{\text {th }}$ Conference on Environmental Science and Technology, Th. Lekkas (Ed.), Vol A, 90-97.

- Tsilingiridis G., Zachariadis Th.. and Samaras Z., (2002), Spatial and temporal characteristics of air pollutant emissions in Thessaloniki, Greece: Investigation of emission abatement measures, The Science of the Total Environment, 300(1-3), 99-113. 